\title{
Antitumor Activity of Lantadenes in DMBA/TPA Induced Skin Tumors in Mice: Expression of Transcription Factors
}

\author{
Jagdeep Kaur $^{1}$, Manu Sharma ${ }^{2}$, P.D. Sharma ${ }^{2}$ and M.P. Bansal ${ }^{1 *}$ \\ ${ }^{1}$ Department of Biophysics, Panjab University, Chandigarh-160014, India \\ ${ }^{2}$ University Institute of Pharmaceutical Sciences, Panjab University, Chandigarh-160014, India \\ *Corresponding author \\ M.P. Bansal \\ Phone: 91-172-2534120 \\ Fax: 91-172-3534118 \\ Email: $\underline{\text { mpbansal@pu.ac.in }}$
}

Received: 8 September 2009; | Revised: 1 November 2009; | Accepted:5 December 2009

\begin{abstract}
Various triterpenoids extracted from plants have been shown as chemopreventive agents in cancer. Lantadene A (22ß-angeoloxyloxy-3-oxoolean-12-en-28-oic acid; LA) is a pentacyclic triterpenoid, isolated from a weed Lantana camara L. and semisynthetically modified to its methyl ester (Methyl22 $\beta$ angeoloxyloxy-3-oxoolean-12-en-28-oate; LAM) were used for the present studies. LA and LAM were studied for its chemopreventive effect on 7, 12-dimethylbenz[a]anthracene (DMBA) followed by 12-Otetradecanoylphorbol-13-acetate (TPA) induced squamous cell carcinoma in Swiss albino mice. The skin lesions were induced by the twice-weekly topical application of DMBA (100nmol/100 $\mu$ l of acetone) for two weeks followed by TPA $(1.7 \mathrm{nmol} / 100 \mu \mathrm{l}$ of acetone) on the depilated back of mice. LA and LAM were administered orally at a dose of $50 \mathrm{mg} / \mathrm{kg}$ body weight twice a week, one week before the topical application of DMBA and continued 20 weeks thereafter. Histopathology of tumors was evaluated in all treatment groups. Previous studies in authors laboratory revealed a significant decrease in incidence and average number of papillomas in mice as compared to DMBA/TPA alone at the end of study. Transcription factors; activator protein-1 (AP-1; c-jun and c-fos), Nuclear factor-kappa B (NF- $\kappa$ B; p65) and p53 were evaluated by using RT-PCR. A significant decrease in the mRNA expression of AP-1 (c-jun and c-fos), NF-kB (p-65) and p53 was observed in LAM and LA treated mice skin tumors. These findings were supported by histopathological studies. From the results, it can be inferred that LAM and LA possesses potential chemopreventive activity and may be linked to the expression of transcription factors.
\end{abstract}

Keywords: Lantadene A; Lantadene A methyl ester; AP-1; NF-кB; p53.

\section{Introduction}

Triterpenoids represent a diverse class of natural products. Recently, pentacyclic triterpenoids have been described to inhibit tumor progression [1]. Lantana camara L. (Verbenaceae) is one of the weeds in tropical and subtropical parts of the world [2]. Its wild growth provides huge amount 
of biomass and currently there is lot of interest to exploit its natural products in drug research [3]. We have earlier reported the chemopreventive effect of the methanolic extract of Lantana camara L. on 7,12-dimethylbenz[a]anthracene (DMBA) induced squamous cell carcinogenesis in

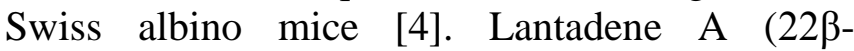
angeoloxyloxy-3-oxoolean-12-en-28-oic acid; LA) is most abundant pentacyclic triterpenoid $(0.7 \%$ on dry weight basis) in the Lantana camara L. var aculeate [5]. LA has been reported to demonstrate inhibition of Epstein-Barr virus activation in Raje cells induced by 12-O-tetradecanoylphorbol-13acetate (TPA) possesses tumor inhibitory activity in two-stage carcinogenesis model in mice [6,7]. However, the molecular mechanism responsible for its tumor inhibitory potential is not well understood. In our earlier publication, we reported the tumor inhibitory activity of LA and its methyl ester (22 $\beta$-angeoloxyloxy-3-oxoolean-12-en-28oate; LAM). LAM was semisynthetically synthesized by methylation of $\mathrm{C}-17$ carboxylic group of LA.

Carcinogenesis is a multistage (initiation, promotion and progression) process that encompasses multiple genetic and epigenetic events $[8,9]$. The rate-limiting steps in multistage carcinogenesis now well understood to occur during tumor promotion and progression. Understanding the molecular basis of these steps is important for prevention of carcinogenesis. Studies $[10,11]$ have implicated transactivation of the transcription factors viz. activator protein-1 (AP-1), nuclear factor kappa B (NF- $\kappa \mathrm{B})$ and $\mathrm{p} 53$, as important in traversing tumor promotion and/or progression. AP-1 regulates the transcription of a number of genes, some of which may mediate neoplastic transformation $[12,13]$. NF-KB exists in the cytoplasm in an inactive form, complexed with an inhibitory protein from the IкB family. These proteins mask a nuclear localization signal on the NF-KB proteins thereby preventing the translocation of NF-KB to the nucleus. It can be activated in cells by a number of inflammatory stimuli including cytokines [14,15] and reactive oxygen species, ROS [16]. p53, a tumor suppressor gene, is activated in response to stressful stimuli such as DNA damage, hypoxia and oncogenes activation. It plays an important role in determining cell's fate following DNA damage. It acts mainly two ways either by arresting cell cycle or by inducing apoptosis. Pivotal role of p53 in regulating the decision to live or die makes it an attractive target for cancer therapeutics [17].

In chemoprevention studies, mouse skin carcinogenesis model is very useful in studying the genetic and biological changes involved in tumor promotion [18]. Some of the genetic changes associated with the chemical initiation of benign papillomas and transition to squamous cell carcinoma have been characterized in this system. In vivo models of multistage mouse skin carcinogenesis have proven useful in elucidating the molecular events that occur during tumor induction [9].

In regulating cellular responses to cytokines and pathogens, the NF- $\kappa \mathrm{B}$ pathway plays an essential role in controlling cellular growth and apoptotic cell death [19]. Consistent with this, inappropriate signaling of NF- $\kappa \mathrm{B}$ has been involved in tumor formation in lymphomas, breast, skin, and bladder cancers [20] and abnormally high $\mathrm{NF}-\kappa \mathrm{B}$ activity and low $\mathrm{I} \kappa \mathrm{B}$ levels which indicates that dysregulation of NF- $\kappa \mathrm{B}$ may also contribute to skin carcinogenesis. Skin tumors show increased levels of AP-1 effector gene expression, correlating with the degree of malignancy [21,22]. Gene products promoting invasion and metastasis are also under AP-1 regulation [23].

Reactive oxygen species (ROS), as causative factors in mutagenesis, carcinogenesis and tumor promotion, have been implicated in the etiology and pathophysiology of human diseases [24]. They modulate gene expression by epigenetic mechanism [25]. Topical application of 12-Otetradecanoylphorbol-13-acetate (TPA) has been reported to increased release of ROS and hence may play an intermediate role in the induction of tumor promotion related genes [26].

Present studies were aimed to characterize the histopathological changes in the DMBA/TPA induced tumors in mice skin after LA and LAM administration. Further, mRNA expression alterations of various transcription factors like NF$\mathrm{\kappa B}, \mathrm{AP}-1$ and $\mathrm{p} 53$ were investigated to find out role of LAM and LA involved in modulation. Because of the critical role of these factors in proliferation, invasion, angiogenesis and 
metastasis of tumors, there is a great interest in their modulators for cancer therapy.

\section{Materials and methods}

\subsection{Chemicals}

7, 12-dimethylbenz( $a$ )anthracene (DMBA), 12-O-tetradacanoylphorbol-13-acetate (TPA), diethyl pyrocarbonate, bovine serum albumin, agarose, ethidium bromide were obtained from Sigma Aldrich St. Louis (USA). Tri reagent was from Mol Res Cent ,Inc,Ohio,USA. Chloroform, isopropanol, ethanol and formamide for total RNA isolation were from Amresco, Ohio (USA).

\subsection{Plant material}

The leaves of Lantana camara were collected in September from Palampur (HP), India. The leaves were shade-dried and powdered. A voucher specimen was deposited in the herbarium at the University Institute of Pharmaceutical Sciences, Panjab University.

\subsection{Animals}

Healthy female Swiss albino mice (LACCA) mice (19-22 g body weight) were obtained from the Central Animal House, Panjab University, Chandigarh. The animals were kept in plastic cages under hygienic conditions and were provided standard animal feed. Before initiating the experiment, the animals were adapted to the laboratory conditions for a week. Necessary approvals were obtained from the Institutional Ethics Committee. The animal care and handling was done according to the guidelines set by the World Health Organization (WHO), Geneva, Switzerland, and the Indian National Science Academy (INSA), New Delhi, India.

\subsection{Experimental design}

Female Swiss albino (LACCA) mice were divided into 4 groups for the present study. Group I animals served as controls. These animals received topical application of acetone $(100 \mu \mathrm{l} / \mathrm{mouse})$ only. Group II animals received topical application of DMBA $(100 \mathrm{nmol} / 100 \mu \mathrm{l}$ of acetone) for two weeks followed by TPA (1.7 $\mathrm{nmol} / 100 \mu \mathrm{l}$ of acetone) twice weekly for 20 weeks. Group III animals were treated as group II mice along with oral administration of $200 \mu \mathrm{l}$ of LAM at the dose level $50 \mathrm{mg} / \mathrm{kg}$ body weight twice a week. Group IV animals were also treated as group II along with oral administration of $200 \mu \mathrm{l}$ of LA at the dose level $50 \mathrm{mg} / \mathrm{kg}$ body weight twice a week for 20 weeks. LAM and LA were administered one week before the topical application of DMBA in group III and group IV respectively.

Lantadene A methyl ester (LAM) and lantadene A (LA) [Fig 1] were synthesized in authors laboratory as published earlier [27]. DMBA was applied topically on depilated back of mice twice a week for two weeks following the topical application of TPA twice a week till end of studies. Body weights of animals were recorded initially and then at 1 week intervals. At the end of experimental period, full grown tumors were selected for the present studies.

\subsection{Histopathological studies}

Tumors and normal skin removed from sacrificed mice were immediately fixed in $10 \%$ formalin fixative for $24 \mathrm{~h}$. The tissues were then dehydrated in ascending series of alcohol, kept in 1:1 mixture of absolute alcohol and benzene and then in benzene for $1 \mathrm{~h}$ each. Finally, tissue pieces were embedded in paraffin wax and 7 micron thick sections were cut and spread on glass slides, stained with hematoxylin and eosin, slides mounted in DPX and viewed under light microscope and photographed.

\subsection{RT-PCR analysis for AP1, NF-kB and p53}

Total RNA isolation: Total RNA isolation was done using TRI-REAGENT (Molecular Research Centre Inc. Ohio, USA). Briefly, 50mg of tissue sample was homogenized in $0.5 \mathrm{ml}$ of TRI-REAGENT, added $0.1 \mathrm{ml}$ chloroform and mixed vigorously. Centrifuged at $12000 \mathrm{~g}$ for 15 $\min$ at $4{ }^{\circ} \mathrm{C}$. Aqueous phase was collected and $250 \mu \mathrm{l}$ of isopropanol was added to precipitate RNA. Centrifuged at $12000 \mathrm{~g}$ for $10 \mathrm{~min}$ at $4^{\circ} \mathrm{C}$, RNA pellet thus obtained washed with $0.2 \mathrm{ml}$ of $75 \%$ ice cold ethanol. Air dried RNA pellet was dissolved in $20 \mu \mathrm{l}$ of diethyl pyrocarbonate (DEPC) treated water and purity checked by determining the ratio of absorbance values at 260 
and 280nm. Concentration of RNA was estimated by measuring $\mathrm{A}_{260}$.

RT-PCR analysis: RT-PCR was done using one step method of RT-PCR kit (QIAGEN, Germany). Briefly, $3 \mu \mathrm{g}$ of RNA template from different groups was used in RT-PCR reaction. Added $10 \mu \mathrm{l}$ of 5X QIAGEN one step RT-PCR buffer (to provide a final concentration of $2.5 \mathrm{mM}$ $\mathrm{MgCl}_{2}$ in the reaction mixture). Added $2 \mu \mathrm{l}$ of dNTP mix (containing $10 \mathrm{mM}$ of each dNTP). Added $5 \mu \mathrm{l}$ of each sense and antisense gene specific primers (from $10 \mu \mathrm{M}$ stock). Then added $2 \mu \mathrm{l}$ QIAGEN one step RT-PCR enzyme mix and $1 \mu \mathrm{l}$ RNAase inhibitor $(1 \mathrm{U} / \mu \mathrm{l})$. Finally PCR grade RNAase free water was added to make total volume $50 \mu \mathrm{l}$. Mixed it gently by vortex and centrifuged to collect all the components at the bottom of the PCR tubes.

After an initial denaturation step of $1 \mathrm{~min}$ at $94^{\circ} \mathrm{C}, 35$ amplification cycles were performed.
Each cycle included an initial denaturation step at $94^{\circ} \mathrm{C}$ for $45 \mathrm{~s}$, annealing at $56^{\circ} \mathrm{C}(\mathrm{NF}-\mathrm{kB})$ or $58^{\circ} \mathrm{C}$ (c-jun, $c$-fos) or $54^{\circ} \mathrm{C}$ (p53) for $45 \mathrm{~s}$ and extension at $72^{\circ} \mathrm{C}$ for $45 \mathrm{~s}$. A final extension step of $5 \mathrm{~min}$ at $72^{\circ} \mathrm{C}$ was performed in order to complete the PCR reaction. The amplified product were analyzed on $1.5 \%$ agarose gel electrophoresis and densitometric analysis of bands was done by Image $\mathbf{J}$ Software (NIH, USA). In order to authenticate the results from RT-PCR (a semiquantitative method) analysis, the analysis was initially carried out at 20,25, 30 and 35 cycles for various genes. Progressive increase in products was obtained in all the cases and hence finally the RT-PCR was done with the samples at 35 cycles only.

The oligonucleotide primer pairs for RT-PCR used in the present study are listed in Table 1.

Table 1: The oligonucleotide primer pairs for RT-PCR used in the study.

\begin{tabular}{|c|c|c|c|c|}
\hline Gene & & Primer & Reference & $\begin{array}{l}\text { Product } \\
\text { Size }\end{array}$ \\
\hline c-jun & $\begin{array}{l}\text { Sense } \\
\text { Antisense }\end{array}$ & $\begin{array}{l}\text { 5'-ATG GGC ACA TCA CCACTA CA-3' } \\
\text { 5'- TGA GTT GGC ACC CAC TGT TA -3' }\end{array}$ & $\begin{array}{l}\text { ACCESSION } \\
\mathrm{X} 12740\end{array}$ & $723 \mathrm{bp}$ \\
\hline c-fos & $\begin{array}{l}\text { Sense } \\
\text { Antisense }\end{array}$ & $\begin{array}{l}\text { 5'-ATG GGC TCT CCT GTC AAC AC-3' } \\
5^{\prime} \text {-ATG ATG CCG GAA ACA AGA AG-3' }\end{array}$ & $\begin{array}{l}\text { ACCESSION } \\
\text { V00727 }\end{array}$ & $715 \mathrm{bp}$ \\
\hline $\begin{array}{l}\text { NF-kB } \\
(p 65)\end{array}$ & $\begin{array}{l}\text { Sense } \\
\text { Antisense }\end{array}$ & $\begin{array}{l}\text { 5'-TGG CGA GAG AAG CAC AGA TA-3' } \\
\text { 5'- TGT TGG TCT GGA TTC GCT G- 3' }\end{array}$ & $\begin{array}{l}\text { ACCESSION } \\
\text { M } 61909\end{array}$ & $272 \mathrm{bp}$ \\
\hline p53 & $\begin{array}{l}\text { Sense } \\
\text { Antisense }\end{array}$ & $\begin{array}{l}\text { 5'-GGG ACA GCC AAG TCT GTT ATG }-3 \text { ' } \\
5^{\prime} \text {-GGA GTC TTC CAG TGT GAT GAT-3' }\end{array}$ & $\begin{array}{l}\text { Chew et al., } \\
2003[44]\end{array}$ & $380 \mathrm{bp}$ \\
\hline$\beta$-actin & $\begin{array}{l}\text { Sense } \\
\text { Antisense }\end{array}$ & $\begin{array}{l}\text { 5'-ATC CGT AAA GAC CTC TAT GC-3' } \\
5^{\prime} \text {-AAC GCA GCT CAG TAA CAG TC-3' }\end{array}$ & $\begin{array}{l}\text { Yamada et al., } 1996 \\
\text { [45] }\end{array}$ & $287 \mathrm{bp}$ \\
\hline
\end{tabular}

\subsection{Statistical analysis}

Statistical analysis of the data was performed by analysis of variances (one way ANOVA) following one way ANOVA post-Hoc test using least significance difference (LSD).

\section{Results}

\subsection{Morphology of tumors and body weight}

Am. J. Biomed. Sci. 2010, 2(1), 79-90; doi: 10.5099/aj100100079
Tumors appearances in mice are shown in Fig. 2. Along with the full tumors, many papillomas are also visible. The average body weight of mice from all treatment groups are shown in Table 2. There was a significant decrease $(p<0.001)$ in the average body weight of DMBA/TPA treated mice observed as compared to control mice. No significant changes were observed in other treatment groups.

(C) 2010 by NWPII. All rights reserved. 
Table 2: Average body weight of mice in grams before and after treatment

\begin{tabular}{|l|l|l|l|}
\hline Groups & Before treatment & $\begin{array}{l}\text { Ten weeks } \\
\text { treatment }\end{array}$ & $\begin{array}{l}\text { Twenty weeks } \\
\text { Treatment }\end{array}$ \\
\hline $\begin{array}{l}\text { Group I } \\
\text { (Control) }\end{array}$ & $19.50 \pm 1.87$ & $24.33 \pm 1.21$ & $28.66 \pm 1.63$ \\
\hline $\begin{array}{l}\text { Group II } \\
\text { (DMBA/TPA) }\end{array}$ & $19.83 \pm 1.72$ & $21.66 \pm 1.86^{*}$ & $24.00 \pm 1.41^{* * * *}$ \\
\hline $\begin{array}{l}\text { Group III } \\
\text { (DMBA/TPA+LAM) }\end{array}$ & $20.00 \pm 1.41$ & $23.66 \pm 1.96$ & $25.50 \pm 1.04$ \\
\hline $\begin{array}{l}\text { Group IV } \\
\text { (DMBA/TPA+LA) }\end{array}$ & $19.83 \pm 1.94$ & $24.00 \pm 1.78$ & $25.56 \pm 1.05$ \\
\hline
\end{tabular}

The values are Mean \pm S.D of 6 independent observations.

$* p<0.05, * * p<0.01, \quad{ }^{* * *} p<0.001$ w.r.t. control mice.

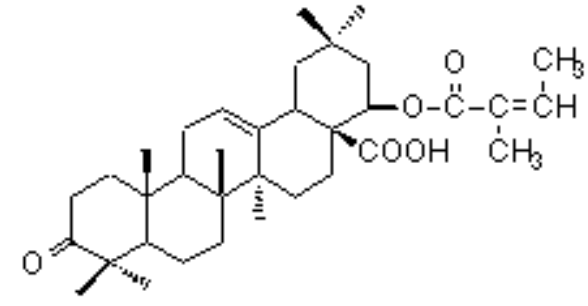

(a)

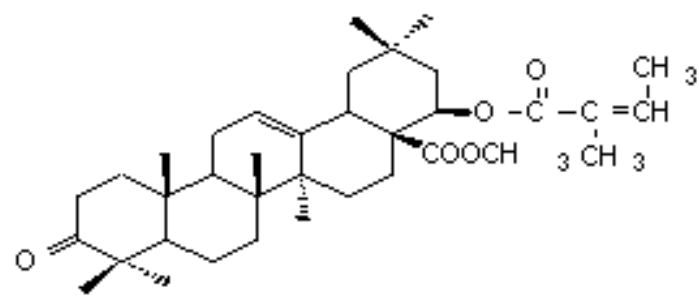

(b)

Figure 1: (a) Structure of Lantadene A (LA) (b) Structure of Lantadene A methyl ester (LAM)

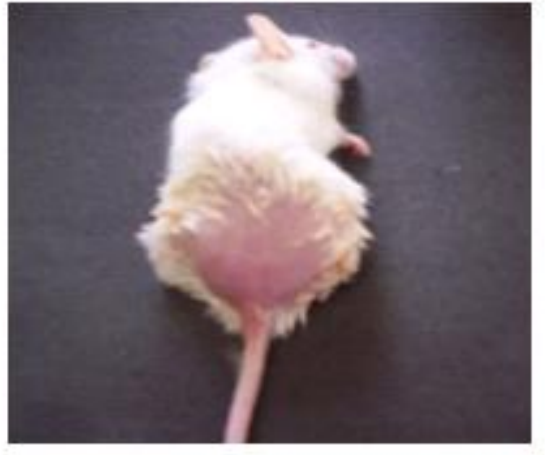

(a)

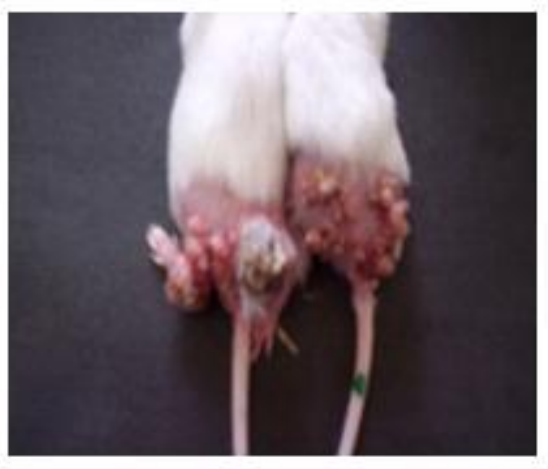

(b)

Figure 2: Mice shown (a) without tumors and (b) with tumors. 


\subsection{Histopathological studies}

The histological changes in the mice tumors and skin were studied with hematoxylin and eosin staining of the paraffin sections in treatment groups. Normal skin in control group I showed normal histology. The uniformly arranged epidermal and dermal layers with normal layer of keratin over the epidermis were observed (Fig. 3a).

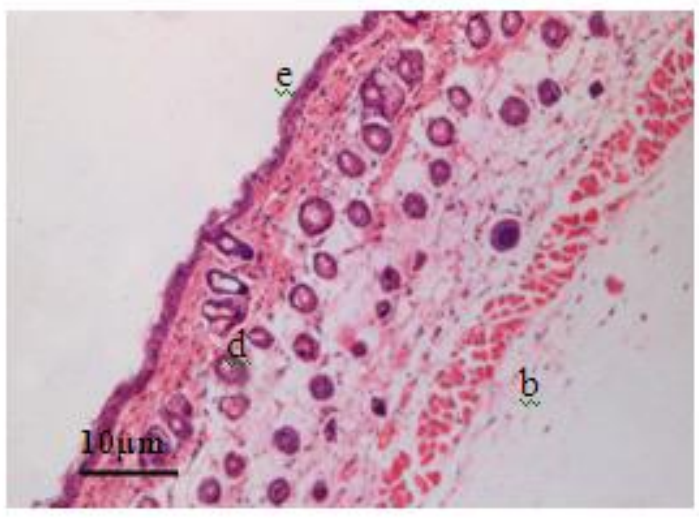

(a)

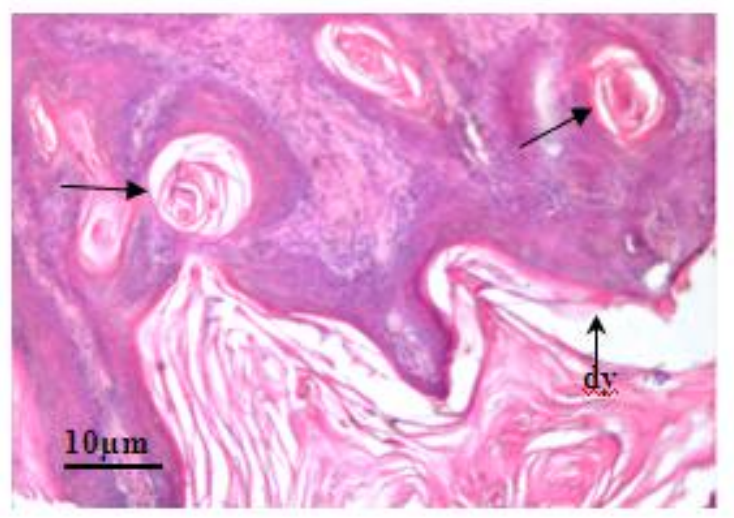

(b)

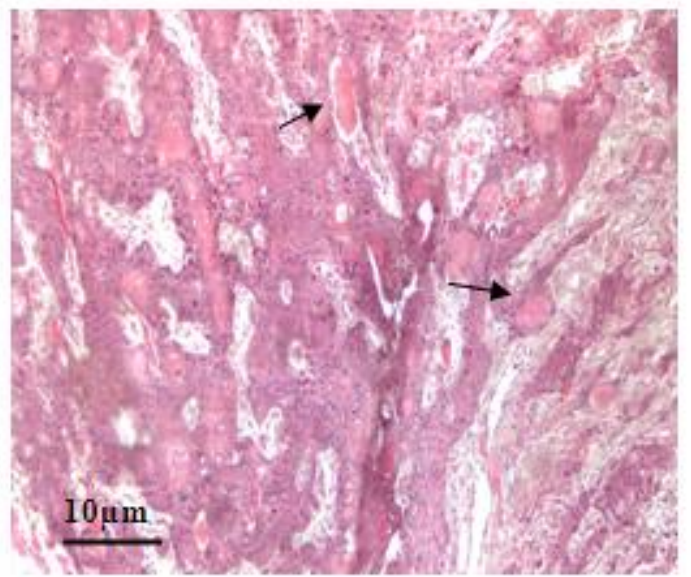

(c)

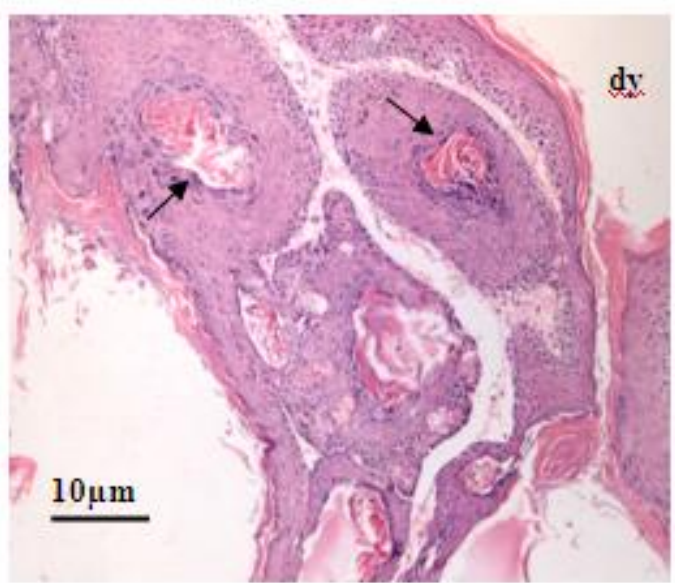

(d)

Figure 3a: Photomicrograph showing histological section of normal skin in mice (group I) [showing e: epidermis, d: dermis, b: basal lamina] x100. 3b: Photomicrograph showing histological section of DMBA/TPA induced skin tumor in mice (group II) [arrows shows keratinocyte pearls and dy labeled arrows showing dyskeratosis, dy] at magnification x100. 3c: Photomicrograph showing histological section of DMBA/TPA induced skin tumor in mice administered with LAM (group III)[arrows shows keratinocyte pearls] at magnification x100 ). 3d: Photomicrograph showing histological section of DMBA/TPA induced skin tumor in mice administered with LA (group IV) [arrows shows keratinocyte pearls and dyskeratosis, dy ] at magnification $\mathrm{x} 100)$. 
(a)

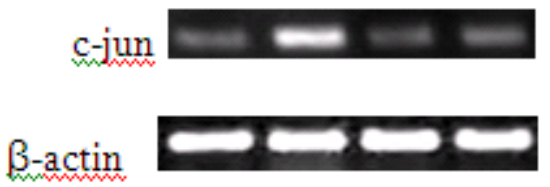

I II III IV (b)

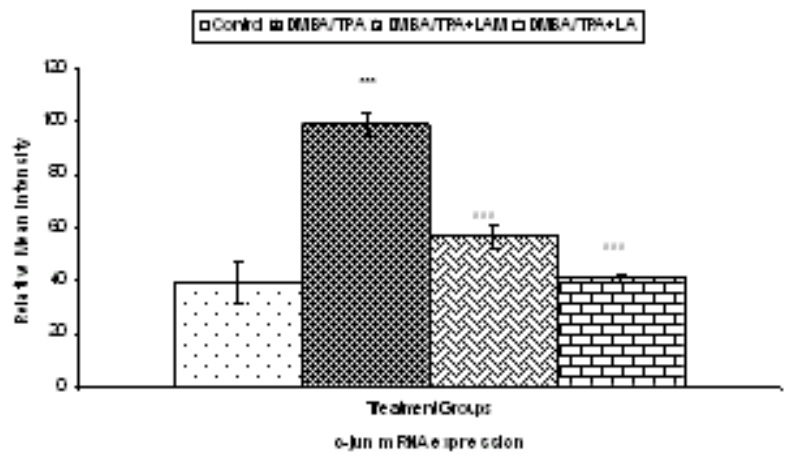

Figure 4: mRNA expression of c-jun and $\beta$-actin (a) and its densitometric analysis (b). Lane I- Control, Lane IIDMBA/TPA treatment, Lane III- DMBA/TPA+LAM treatement, Lane IV- DMBA/TPA+LA treatment. The values are mean \pm SD of four independent observations. *, $* *, * * *$ Represent $p<0.05, p<0.01, p<0.001$, w.r.t control and \#, \#\#, \#\#\# Represent $p<0.05, p<0.01, p<0.001$, w.r.t DMBA/TPA treatment respectively.

(a)

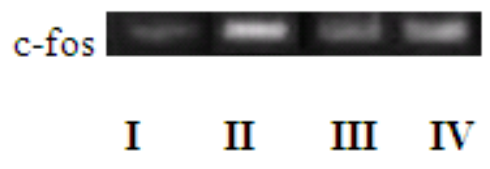

(b)

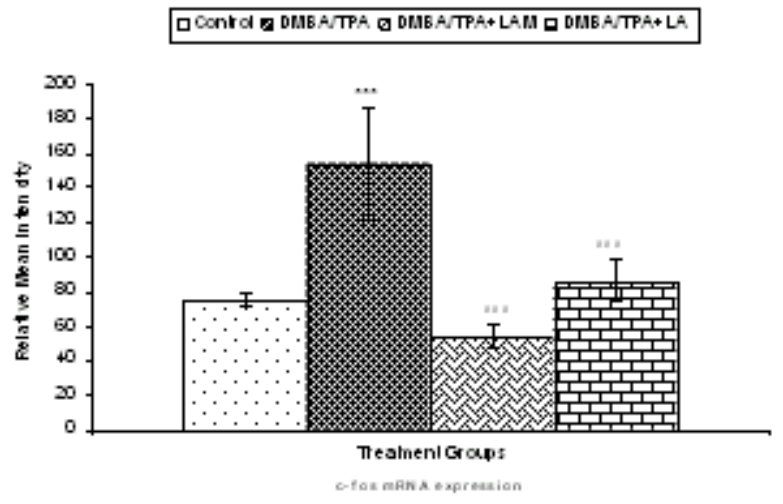

Figure 5: mRNA expression of c-fos (a) and its densitometric analysis (b). Lane I- Control, Lane II- DMBA/TPA treatment, Lane III- DMBA/TPA+LAM treatement, Lane IV- DMBA/TPA+LA treatment. The values are mean \pm SD of four independent observations. ${ }^{*}, * *, * * *$ Represent $p<0.05, p<0.01, p<0.001$, w.r.t control and \#, \#\#, \#\#\# Represent $p<0.05, p<0.01, p<0.001$, w.r.t DMBA/TPA treatment respectively.

In histopathological sections of DMBA/TPA treated mice tumors (group II), dyskeratosis of the epidermis and abnormally thickened epidermis, with deposition of keratinocyte pearls was observed in dermis and epidermis. Hyperkeratosis i.e. thickening of keratinized layer over the epidermis was also observed (Fig. 3b).

The extent of lesion was much less in DMBA/TPA+LAM treated mice tumors (group III) as compared to DMBA/TPA treated tumors of group II. Abnormally thickened epidermis was observed in skin tumor section (Fig. 3c). The Am. J. Biomed. Sci. 2010, 2(1), 79-90; doi: 10.5099/aj100100079 extent of keratinocyte pearls was much less as compared to DMBA/TPA treated tumors of group II. Also, much reduction in size of keratinocyte pearls was observed.

The extent of lesions developed in DMBA/TPA+LA treated mice tumors (group IV) was less as compared to DMBA/TPA treated tumors of group II. Abnormally thickened epidermis was also observed in skin tumor section (Fig. 3d). The extent of keratinocyte pearls were less as compared to DMBA/TPA treated mice of group II. Also the compactness of keratinocyte 
pearls was observed but was less as compared to DMBA/TPA treated tumors.

\section{3 mRNA expression studies by RT-PCR}

RT-PCR products of c-jun, c-fos, NFkB (p65) and p53 on agarose gel electrophoresis showed bands of respective expected sizes in mice tumors and control skin in various groups (Fig. 4a, 5a, 6a and 7a). mRNA expression for $\beta$-actin, a house keeping gene, was studied simultaneously with every target gene to keep a check on any background error. The densitometric analysis of mRNA expression in each group was also carried and statistically compared (Fig 4b, 5b, 6b and 7b). Significant increase in the expression of cjun, c-fos, p65 and p53 were observed in DMBA/TPA treated mice tumors (group II) in comparison to control mice skin of group I. DMBA/TPA+LAM (group III) treatment resulted in significantly decreased expression of c-jun, c0fos, p65 and p53 in comparison to DMBA/TPA treated mice tumors of group II. Also the expression of c-jun, c-fos, p65 and p53 were significantly decreased $(p<0.001)$ in DMBA/TPA+LA (group IV) treatment as compared to DMBA/TPA treated mice tumors of group II. (a)

p65

\section{II III IV}

(b)

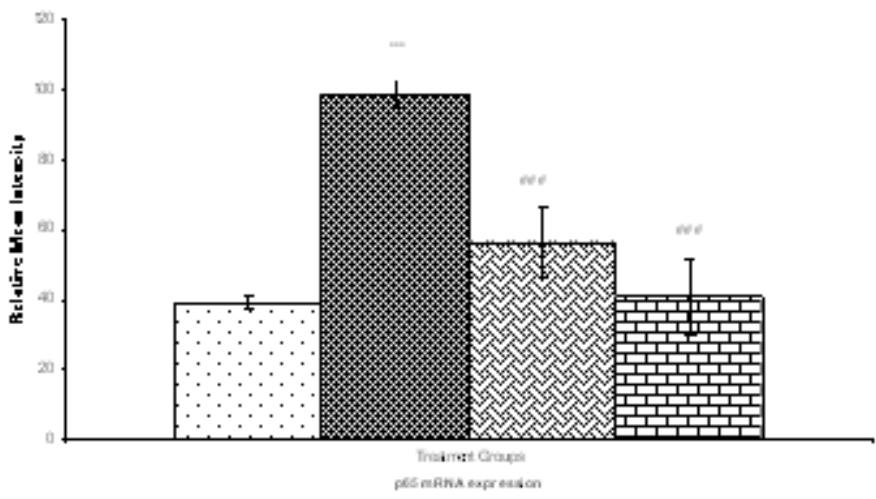

Figure 6: mRNA expression of p65 (a) and its densitometric analysis (b). Lane I- Control, Lane II- DMBA/TPA treatment, Lane III- DMBA/TPA+LAM treatement, Lane IV- DMBA/TPA+LA treatment. The values are mean \pm SD of four independent observations. $\quad *, * *, * * *$ Represent $p<0.05, p<0.01, p<0.001$, w.r.t control and \#, \#\#, \#\#\# Represent $p<0.05, p<0.01, p<0.001$, w.r.t DMBA/TPA treatment respectively.

(a)

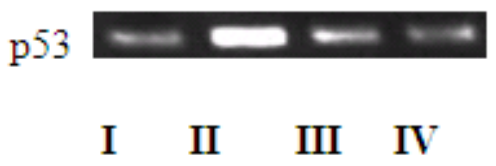

(b)

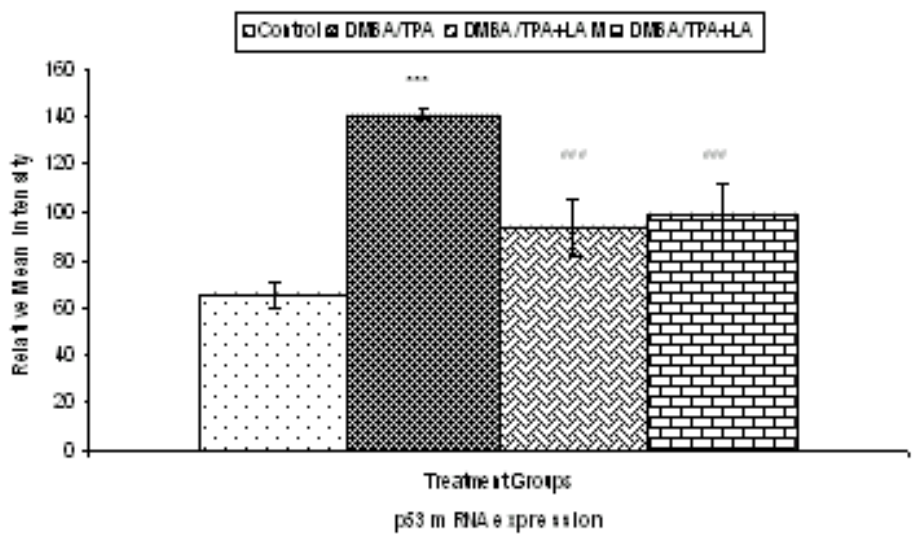

Figure 7: mRNA expression of p53 (a) and its densitometric analysis (b). Lane I- Control, Lane II- DMBA/TPA treatment, Lane III- DMBA/TPA+LAM treatement, Lane IV- DMBA/TPA+LA treatment. The values are mean \pm SD of four independent observations. $\quad *, * *, * * *$ Represent $p<0.05, p<0.01, p<0.001$, w.r.t control and \#, \#\#, \#\#\# Represent $p<0.05, p<0.01, p<0.001$, w.r.t DMBA/TPA treatment respectively.

Am. J. Biomed. Sci. 2010, 2(1), 79-90; doi: 10.5099/aj100100079 @ 2010 by NWPII. All rights reserved. 


\section{Discussion}

In the present study, while studying the chemopreventive effect of LAM and LA on mouse skin DMBA/TPA induced carcinogenesis model, a significant decrease of the average body weights as compared to the normal control mice was observed. The reduction in body weights can be attributed to the initiation of carcinogenesis induced by DMBA/TPA, which might be a result of metabolic changes. Similarly, decrease in average body weight in the conditions of DMBAinduced squamous cell carcinoma of skin $(26,28)$. However supplementation of LA and LAM to DMBA/TPA treated mice did not show any significant change when compared with DMBA/TPA treated mice.

The histopathological sections of control skin (group I) showed uniformly arranged epidermis and dermis layer resting upon basal lamina. However, in histopathological sections of DMBA/TPA induced skin tumors of group II, abnormally thickened epidermis with irregular proliferation and deposition of keratinocyte pearls were observed in dermis and epidermis. Hyperkeratosis i.e. thickening of keratinized layer over the epidermis was also observed in skin tumors in group II. Also the invasive growth of keratin inward, into the epidermis was observed in skin tumors of this group. These results are supported by previous findings that DMBA/TPA treatment results in necrotic keratinized pearls, suggesting invasive squamous cell carcinoma (26). Whereas in DMBA/TPA+ LAM treatment (group III), the extent of lesions was less as compared to group II. Keratinocyte pearls were observed but of reduced size in this group. This may be due to that LAM administration resulted in inhibition in cell proliferation and inhibited further growth and promotion of skin tumors induced by DMBA/TPA. The extent of lesions was also less in group IV (DMBA/TPA +LA). Dyskeratosis and keratinocyte pearls were observed to be much less in skin tumors as compared to group II.

Further, to find the molecular mechanism of the inhibition of tumors with LAM and LA, the AP-1, NF-кB and p53 transcription factors were studied in tumors from all treatment groups.
There was a significant increase in the expression (mRNA) of c-jun and c-fos (homodimers of AP-1) in DMBA/TPA treatment group. Identification of Jun and Fos as mammalian cellular homologues of retroviral oncoproteins ( $\mathrm{v}$ Jun and v-Fos), together with the finding that growth factors and tumor promoters induce AP-1 activity, immediately linked AP-1 to cellular growth control and neoplastic transformation (29). However decrease in expression of c-jun and c-fos was observed in LAM and LA supplementation treatment groups. Inhibition of AP-1 was significantly inhibited by LAM and LA. Considering the important role of AP-1 in tumor promotion, this inhibition may be functionally related to its chemopreventive effect.

A functional role for AP-1 components in the epidermis of the skin has been suggested for differentiation, carcinogenesis, UV-response, photo-aging and wound repair (30). This might be due to regulation of AP-1 which can be achieved at different levels by changes in transcription of genes encoding AP-1 subunits by controlling the stability of the mRNAs, by posttranslational processing, turnover and modification by phosphorylation of AP-1 proteins, and by specific interaction between AP-1 proteins and other transcription factors and cofactors (31)

NF-KB has been implicated in carcinogenesis as it plays a critical role in cell survival, cell adhesion, inflammation, differentiation and cell growth. Cancer is a hyperproliferative disorder that results from tumor initiation and promotion and ultimately produces tumor metastasis. Several genes involved in cellular transformation, proliferation, invasion and angiogenesis are regulated by NF-KB (32). Oxidant stress can result in degradation of cytoplasmic NF- $\mathrm{KB}$ inhibitor, IKB and its translocation to the nucleus [33].

Presently, the mRNA expression of p65 increased significantly in DMBA/TPA treated group (group II). This indicates activation of NF$\mathrm{kB}$, which is probably due to inhibition of $\mathrm{I \kappa B}$ protein that resides in the cytoplasm and hence, increased level of p65 expression in the nuclear fraction. The constitutive activation of NF-KB also appears to have role in cell proliferation [34]. Whereas in control (group I), there was decrease in expression. However a decrease in expression 
was also observed in LA (group IV) and LAM (group III) treated groups. This may be due to suppression of NF-KB by these compounds. We consider that signaling pathway might be a target for LA and LAM. Several chemopreventive agents are inhibitors of NF-kB activation. These inhibitors can block any one or more steps in the $\mathrm{NF}-\mathrm{KB}$ signaling cascade, the translocation of NF$\mathrm{KB}$ into the nucleus, DNA binding of the dimers and interactions with the basal transcription activation [35].

The tumor suppressor gene, p53 is regarded as a key factor in maintaining the balance between cell growth and cell death $[36,37]$. The p53 tumor suppressor gene plays a pivotal role in protecting cells from cancer development. The inactivation of p53 which is known as the guardian of the human genome, causes genetic instability leading to the accumulation of genetic alterations, which induce malignant transformation of cells. In addition, it was found that mutant $\mathrm{p} 53$ protein that frequently accumulates in human tumors , facilitates tumor initiation and progression by a "gain of function" mechanism.

The p53 tumor suppressor gene plays a preeminent role in protecting cells from malignant transformation. p53 protein is an astute watchdog over the physical integrity of the cellular genome [38]. The importance of p53 gene can be drawn from the fact that this gene is reported to be mutated in $80 \%$ of the all human malignancies [39]. Because of its role in regulation of cell cycle, alterations in p53 are critical events in carcinogenesis [40]. The p53 protein is normally present minute amounts in cells but when cells are exposed to genotoxic stimuli, p53 levels rise rapidly and initiate a programme of cell death, probably by means of transcriptional regulation. This response is lost in many tumor cells as they have either in activated their p53 genes by mutation or blocked the activity of p53 through the production of proteins that bind to it and neutralize it [41]. In the present study, a decrease in mRNA expression of p53 was seen in control (group I) and a significant increase in the p53 expression was observed in DMBA/TPA (group II) treated mice tumors. Also it was seen that decrease in expression of p53 in LAM (group III) and LA (group IV) supplementation groups of treatment groups was observed. Many chemopreventive agents are known to exert their anticancer effects through the induction of apoptosis via p53 dependent mechanisms [42,43]. Mutant p53 proteins accumulate to high levels in many cancer cells and the p53 protein and the p53 response to DNA damage represent key points for therapeutic intervention [41].

Hence the overall studies indicate that the compounds LA and LAM were ameliorating the effects of DMBA/TPA induced skin carcinogenesis at transcription levels.

\section{Acknowledgement}

We thank Indian Council of Medical Research for SRF to one of the author.

\section{References}

1. Connolly, J.D.; Hill, R.A. Triterpenoids, Nat Prod Res, 2005, 22, 487-503.

2. Sharma, O.P.; Vaid, J.; Sharma, P.D. Comparison of lantadenes and toxicity of different taxa of the lantana plant, J Chem Ecol, 1991, 17, 2283-2291.

3. Ghisalberti, E.L. Lantana camara (Verbenaceae), Fitoterapia, 2000, 71, 22832291.

4. Sharma, M.; Sharma, P.D.; Bansal, M.P. Chemopreventive effect of Lantana camara leaf extract on 7,12-Dimethylbenz[a]anthraceneinduced squamous cell carcinoma of skin in swiss albino mice, Pharma Biol, 2007, 45, 45148.

5. Sharma, M.; Sharma, P.D. Optimization of lantadene isolation and preparation of $22 \beta$ hydroxy oleanolic acid, Chem Nat Comp, 2006, 42, 442-444.

6. Inada, A.; Nakanishi, T.; Tokuda, H.; Nishino, H.; Iwashina, A.; Sharma, O.P. Inhibitory effects of Lantadenes and related tri-terpinoids on Epstein-Barr virus activation, lanta Med, $1995,61,558-559$.

7. Inada, A.; Nakanishi, T.; Tokuda, H.; Nishino, H.; Iwashina, A.; Sharma, O.P. Anti-tumor promoting activities of Lantadenes on mouse skin tumors andmouse hepatic tumors, Planta Med, 1997,63, 272-274. 
8. Bickers, D.R.; Lowy, D.R. Carcinogenesis: a fifty-year historical perspective, J Invest Dermatol, 1989, 92, 121-131.

9. Brown, K.; Balmain, A. Transegenic mice and squamous multistage skin carcinogenesis. Cancer Metastasis Rev, 1995, 14, 113-124.

10. Dong, Z.; Birrer, M.; Watts, R.; Matrisian, L.; Colburn, N.H.. Blocking of tumorpromoterinduced AP-1 activity inhibits induced transformation in JB6 mouse epidermal cells, Proc Natl Acad Sci USA, 1994, 91, 609-614

11. Li, J.J.; Rhim, J.S.; Schlegel, R.; Vousden, K.H.; Colburn, N.H. Expression of dominant negative Jun inhibits elevated AP-1and NFkappa B transactivation and suppressors anchorage independent growth of HPV immortalized human keratinocytes, Oncogene, 1998, 16, 2711-2721.

12. Angel, P.; Imagawa, M.; Chiu, R.; Stein, B.; Imbra, R.J.; Rahmsdorf, H. J.; Jonat, C.; Herrlich, P.; Karin, M.. Phorbol ester-inducible genes contain a common cis element recognized by a TPA-modulated transacting factors, Cell ,1987,49, 729-739.

13. Matrisian, L.M.. Matrix metalloproteinase gene expression, Ann N Y Acad Sci, 1994, 732, 4250.

14. Bone, R.C.; Balk, R.A.; Cerra, F.B.;Dellinger, R.P.;Fein, A.M.;Knaur, W. A. Definitions for sepsis and organ failure and guidelines for the use of innovative therapies for sepsis, Chest, 1992, 101, 1644-1655.

15. Ben-Shaul, V.; Lomintski, L.; Nyska, A.; Zurovsky, Y.; Berman, M.; Grossman, S. The effect of natural antioxidants, NAO and apocynin on oxidative stress in the rat heart following LPS challenge, Toxicol Lett, 2001,123, 1-10.

16. Barnes, P.J. Nuclear factor-kB, Int J Biochem Cell Biol, 1997, 29, 867-870.

17. Levesque, A.A.; Eastman, A.. p53 based cancer therapies: is defective p53 is the Achilles heel of the tumor?, Carcinogenesis, 2007, 28, 13-20.

18. Holden, P.R.; MGuire, B.; Stoler, A.; Balmain, A.; Pitts, J.D. Changes in gap junctional intercellular communication in mouse skin carcinogenesis, Carcinogenesis, 1997,18, 1521.
19. Baichwal, V.R.; Baeuerle, P.A. Activate NFkappa B or die?, Curr Biol, 1997,7, 94-96. 20. Dejardin, E.; Deregowski, V.; Chapelier, M.; Jacobs, N.; Gielen, J.; Merville, M.P.; Bours, V. Regulation of NF-kappaB activity by I kappaB-related proteins in adenocarcinoma cells, Oncogene, 1999,18, 2567-2577.

21. Ostrowski, L.E.; Finch, J.; Krieg, P.; Matrisian, L.; Patskan, G.; O'Connell, J.F.; Phillips, J.; Slaga, T.J.; Breathnach, R.; Bowden, G.T. Expression pattern of a gene for a secreted metalloproteinase during late stages of tumor progression, Mol Carcinog, 1988, 1, 13-19.

22. Hashimoto, Y.; Tajima, O.; Hashiba, H.; Nose, K.; Kuroki, T. Elevated expression of secondary, but not early, responding genes to phorbol ester tumor promoters in papillomas and carcinomas of mouse skin, Mol Carcinog ,1990,3, 302-308.

23. Lamb, R.F.; Hennigan, R.F.; Tumbull, K.; Katsanakis, K.D.; MacKenzie, E.D.; Bimie, G.D.; Ozanne, B.W. AP-1-mediated invasion requires increased expression of the hyaluronan receptor CD44, Mol Cell Biol, 1997, 17, 963976.

24. Siesh, H. Srtrategies of antioxidant defence, Eur J Biochem, 1993, 215, 213-219.

25. Cerutti, P.A.. Prooxidant states and tumor promotion. Science, 1985, 227, 375-381.

26. Dhawan, D.; Balasubramaniam, S.; Amonkar, A.J.; Singh, N. Chemopreventive effect of 4'dimethyl epipophyllotoxin on DMBA/TPAinduced mouse skin carcinogenesis, Carcinogenesis, 1999, 20, 997-1003.

27. Sharma, M.; Sharma, P.D.; Bansal, M.P.; Singh, J. Synthesis, Cytotoxicity and Antitumor activity of Lantadene-A Cogeners, Chem \& BioDiv, 2007, 4, 932-939.

28. Prakash, J.; Gupta, S.K.; Dinda, A.K. Withania sominifera root extracts prevents DMBA induced squamous cell cacrcinoma in swiss albino mice, Nutrition and Cancer, 2002, 42, 91-97.

29. Shaulian, E.; Karin, M. AP-1 as a regulator of cell life and death, Nat Cell Biol, 2002, 4, 131136.

30. Angel, P.; Szabowski, A.; Schorpp-Kistner, M. Function and regulation of AP-1 subunits in 
skin physiology and pathology, Oncogene, 2001, 20, 2413-2423.

31. Hess, J.; Angel, P.; Schorpp-Kistner, M.. AP-1 subunits: Quarrel and harmony among siblings, J Cell Sci, 2004,117, 5965-5973.

32. Aggarwal, B.B.; Sethi, G.; Nair, A.; Ichikawa, Н. Nuclear Factor-кB: A holy grail in cancer prevention and therapy, Curr Sign Transd Therapy, 2006,1, 25-52.

33. Asehnoune, K.; Strassheim, D.; Mitra, S.; Kim, J.Y.; Abraham, E. Involvement of reactive oxygen species in Toll-like receptor 4dependent activation of NF-kappaB, $J$ Immunol ,2004,172, 2522-2529.

34. Asakura, M.; Kitakaze, M.; Takashima, S.;Liao Y.; Ishikura, F. Cardiac hypertrophy is inhibited by antagonism of ADAM 12 processing of HB-EGF: metalloproteinase inhiubitors as new therapy, Nat Med, 2002, 8, 35-40.

35. Bharti, A.C.; Donato, N.; Singh, S.; Aggarwal, B.B. Curcumin (diferuloylmethane) downregulates the constitutive activation of nuclear factor-kappa B and IkappaBalpha kinase in human multitude myeloma cells, leading to suppression of proliferation and induction of apoptosis, Blood, 2003, 101, 1053-1062.

36. Agarwal, M.L.; Taylor, W.R.; Chernov, M.V.; Chernova, O.B.; Stark, G.R.. The p53 network, J Biol Chem , 1998, 273, 1-4.

37. Mowat, M.R. p53 in tumor progression: life, death and everything, Adv Cancer Res, 1998, 74, 25-48.
38. Mall, U.M.; Schramm, L.M. p53- An acrobat in tumorigenesis, Crit Rev Oral Biol Med, 1998, 9, 23-37.

39. Hollstein, M; Sidransky, D.; Vogelstein, B.; Harris, C.C. p53 mutations in human cancers, Science, 1991, 253, 49-53.

40.Arora,A.;Siddiqui,I.A.;Shukla,Y.Modulation of p53 in 7,12-dimethylbenz[a]anthraceneinduced skin tumors by diallyl sulfide in Swiss albino mice Mol Cancer Ther, 200, 43, 14591466.

41. Lane, D.P. p53 and Human Cancers, Brit Med Bull, 1994, 50, 582-599.

.42. Huang, C.; Ma, W.Y.; Goranson, A.; Dong, Z. Resveratrol suppresses cell transformation and induces apoptosis through a p53-dependent pathway, Carcinogenesis, 1999, 20, 237-242.

43. She, Q.B.; Bode, M.; Ma, W.Y.; Chen, N.Y.; Dong, Z. Resveratrol-induced activation of p53 and apoptosis is mediated by extra cellular signal regulated protein kinases and p38 kinase, Cancer Res, 2001, 61, 1604-1610.

44. Chew, B.P.;Cynthia, M.B.; Jean, S.P.; Philip, F.M. Dietry lutein inhibits mouse mammary tumor growth by regulating angiogenesis and apoptosis, Anticanc Res, 2003,23, 333-334.

45. Yamada, K.; Takane-Gyotoku, N.;Yuan, X,; Ichikawa, F,; Inada, C.; Nonaka, K. Mouse islet cell lysis mediated by inter leukin-1 induced Fas, Diabetologia, 1996, 39, 1306-1313. 